\title{
FAKTOR-FAKTOR PENDORONG IBU DALAM MEMBERIKAN ASI EKSKLUSIF DI UPT PUSKESMAS II DENPASAR BARAT
}

\author{
*Ni Ketut Martini ${ }^{(1)}$ Ni PutuWidya Astuti ${ }^{(2)}$ \\ ${ }^{1,2}$ Program Studi Kesehatan Masyarakat Universitas Dhyana Pura, Badung, Bali, Indonesia \\ *Email : martiniketut910@yahoo.co.id
}

\begin{abstract}
ABSTRAK
Menyusui adalah proses alami bagi seorang ibu untuk menghidupi dan mensejahterakan anak setelah melahirkan. Proses menyusui tidak mudah karena memerlukan kekuatan agar dapat berhasil memberikan ASI eklusif pada bayinya. Cakupan ASI eksklusif di wilayah kerja Puskesmas II Denpasar terendah di Kota Denpasar, namun masih cukup banyak yaitu sebesar 63,6 \% ibu yang lulus memberikan ASI Eksklusif. Hasil penelitian pengetahuan yang baik tentang ASI sangat mendukung keberhasilan pemberian ASI eksklusif. Motivasi diri sendiri dan dukungan keluarga responden dapat mendorong keberhasilan pemberian ASI eksklusif. Perilaku IMD pada ibu dapat mendukung keberhasilan pemberian ASI eksklusif. Sebagian besar responden yang bekerja berhasil memberikan ASI eksklusif pada bayinya. Penelitian ini bertujuan untuk mengetahui faktor-faktor pendorong ibu dalam pemberian ASI esklusif pada bayi usia 0-6 bulan. Metode penelitian yang digunakan adalah kualitatif dengan rancangan penelitian cross sectional. Subyek penelitian adalah ibu yang mempunyai bayi umur 6-12 bulan yang lulus memberi ASI eksklusif di Wilayah kerja UPT Puskesmas II Denpasar Barat. Pengumpulan data dilakukan melalui wawancara mendalam dengan responden dipilih melalui metode purposive sampling sebanyak 10 orang.
\end{abstract}

Kata Kunci: ibu, bayi umur 0-6, ASI eksklusif dan faktor pendorong

\begin{abstract}
Breastfeeding is a natural process for a mother to support and welfare of the child after birth. Breastfeeding is not easy because it requires strength to successfully deliver their babies exclusively breast milk. Scope of exclusive breastfeeding in Puskesmas second lowest in Denpasar, but still quite a lot that is equal to $63.6 \%$ of women who graduated exclusive breastfeeding. The results of the study a good knowledge about breastfeeding support the success of exclusive breastfeeding. Self motivation and family support respondents can drive the success of exclusive breastfeeding. IMD maternal behavior can support the success of exclusive breastfeeding. Most of the respondents who work successfully exclusive breastfeeding her baby. This study aims to determine the factors driving mother in exclusive breastfeeding in infants aged 0-6 months. The method used is qualitative with cross sectional study design. Subjects were mothers of infants aged 6-12 months were passed giving exclusive breastfeeding at work UPT Puskesmas II Region West Denpasar. Data collection was conducted through in-depth interviews with respondents selected through purposive sampling method as many as 10 people.
\end{abstract}

Keywords: mothers, aged 0-6, exclusive breastfeeding and the factors driving

\section{PENDAHULUAN}

Anjuran World Health Organization (WHO) agar ibu memberikan Air Susu Ibu (ASI) yang baik dan benar adalah menyusui bayi secara esklusif sejak lahir sampai umur 6 bulan dan meneruskan menyusui anak sampai umur 2 tahun. Mulai 6 bulan, bayi mendapat makanan pendamping ASI yang bergizi sesuai dengan kebutuhan tumbuh kembangnya (Depkes RI, 2007).

ASI eksklusif adalah menyusui bayi secara murni. Yang dimaksud secara murni adalah bayi hanya di beri ASI saja selama 6 bulan tanpa tambahan cairan apapun, seperti susu formula, jeruk, madu, air teh, air putih dan tanpa pemberian makanan tambahan lain, seperti pisang, bubur susu, biscuit, bubur atau nasi tim. Setelah bayi berusia 6 bulan, barulah bayi di berikan makanan pendamping (Natia, W.R, 2013).

ASI adalah satu zat yang terbaik yang dimiliki manusia sebagai makanan bayi. Setiap bayi harus diberi ASI paling tidak selama 4 bulan pertama dan lebih baik lagi 
jika selama 6 bulan pertama hidupnya. Agar tidak ada keraguan apakah seorang bayi bisa mendapatkan protein dari sumber lain, maka bayi harus terus menerima ASI selama 2 tahun atau lebih. Menurut Gupte, 2011 dalam Almira, S. (2011) ASI bukanlah makanan yang buruk bagi bayi, tetapi makanan pilihan untuk bayi.

Rekomendasi pemberian ASI eksklusif sampai usia 6 bulan tampaknya masih sulit untuk dilaksanakan. Upaya agar ibu biasa menyusui bayinya secara eksklusif sampai usia 6 bulan masih memiliki banyak kendala, hal ini dapat dilihat dari target program pada tahun 2014 yaitu sebesar $80 \%$. Secara nasional cakupan pemberian ASI esklusif pada tahun 2014 diketahui hanya tercapai sebesar $52,3 \%$ sehingga belum bisa mencapai target nasional yang sudah di tetapkan, cakupan ASI esklusif di Provinsi Bali sebesar 72,2\% (Depkes RI, 2014).

Cakupan Pemberian ASI esklusif tahun 2014 di kota Denpasar sebesar 73,33\%. Cakupan ASI esklusif tertinggi diwilayah kerja Puskesmas I Denpasar Timur sebesar $77,10 \%$ dan terendah oleh Puskesmas II Denpasar Barat hanya sebesar $63,60 \%$. Bila dibandingkan dengan target Renstra Dinas Kesehatan Kota Denpasar tahun 2014 sebesar $76 \%$, hanya 2 puskesmas yang memenuhi target, yaitu Puskesmas I Denpasar Timur dan Puskesmas II Denpasar Selatan (Dinkes Denpasar, 2014).

Penelitian tentang keberhasilan pemberian ASI eksklusif yang dilakukan di Surabaya, menunjukan bahwa kekuatan yang menyebabkan ibu berhasil menyusui lebih dari 6 bulan adalah kesadaran diri, dukungan, afeksi positif, sikap yang kuat dan baik, tujuan yang terarah dan kesejahteraan.

Berdasarkan hal tersebut, penelitian ini di lakukan untuk mengetahui tentang faktorfaktor pendorong ibu dalam pemberian ASI esklusif pada bayi usia 0-6 bulan wilayah kerja UPT Puskesmas II Denpasar Barat.

\section{METODE}

\section{Rancangan Penelitian}

Penelitian ini merupakan penelitian deskriptif yaitu suatu penelitian yang dilakukan untuk mendiskripsikan suatu fenomena yang terjadi di dalam masyarakat (Notoadmojo, 2010) dengan jenis penelitian kualitatif. Penggunaan kualitatif di pilih agar proses pengidentifikasian dan penguraian faktor-faktor pendorong pemberian ASI eksklusif dapat mudah di lakukan.

Menurut Maleong, 2016 dalam Afifah (2007), metode kualitatif lebih mudah menyesuaikan apabila berhadapan dengan kenyataan ganda, lebih peka dan lebih dapat menyesuaikan diri dengan banyak penajaman pengaruh bersama terhadap polapola nilai yang dihadapi, dan metode kualitatif menyajikan secara langsung, dan melihat hubungan peneliti dan informan.

\section{Analisis Data}

Proses pengumpulan data rekaman hasil wawancara mendalam kemudian dianalisis secara kualitatif melalui tahapan-tahapan. Tahapan tersebut adalah mengorganisasikan data, pengelompokan berdasarkan kategori, tema dan pola jawaban, menguji asumsi atau permasalahan terhadap data, mencari alternatif penjelasan bagi data, menulis hasil penelitian (Pradipta, 2012).

\section{HASIL DAN PEMBAHASAN \\ Gambaran umum Puskesmas II Denpasar Barat}

Puskesmas II Denpasar Barat didirikan di Denpasar pada tanggal 31 Oktober 1984 yang terletak di Jalan Gunung Soputan, Gang Puskesmas No 3 Denpasar Barat. Luas wilayah kerja yaitu kurang lebih 13,44 Km2. Puskesmas II Denpasar Barat mewilayahi 5 desa dan 1 kelurahan yang meliputi 58 banjar yaitu:

Desa Pemecutan Klod terdiri dari 15 banjar, Desa Dauh Puri Kauh terdiri dari 7 banjar, Kelurahan Dauh Puri terdiri dari 3 banjar dan 5 lingkungan, Desa Dauh Puri Klod terdiri dari 11 banjar, Desa Padang Sambian Kelod terdiri dari 12 banjar dan Desa Dauh Puri Kangin terdiri dari 5 Banjar.

Sarana pelayanan kesehatan mempunyai peranan yang sangat penting dalam meningkatkan derajat kesehatan masyarakat. Pada wilayah puskesmas terdapat beberapa sarana pelayanan kesehatan milik pemerintah dan swasta. Serta terdapat pula bentuk upaya kesehatan yang berbasis dan bersumber daya masyarakat seperti Posyandu. Dan jumlah posyandu di Puskesmas II Denpasar Barat sebanyak 73 posyandu dari 5 desa dan 1 kelurahan.

\section{Karakteristik subjek}

Pada penelitian ini, responden sebagai subyek penelitian adalah ibu yang memiliki bayi usia 6-12 bulan yang berjumlah 12 
orang. Usia responden berkisara antara 2635 tahun.

Mayoritas pekerjaan responden adalah sebagai pegawai swasta sebanyak 8 orang dan 4 orang sebagai ibu rumah tangga.

Pendidikan responden lulusan SMA sebanyak 5 orang dan dengan lulusan Sarjana sebanyak 4 orang dan diploma sebanyak 3 orang. Sebagian besar responden memiliki bayi usia 9 bulan dan merupakan anak pertama dan ada juga responden yang memiliki dua orang, jarak kelahiran 3 sampai dengan 6 tahun.

Mayoritas pekerjaan suami sebagai pegawai swasta, adik kandung subjek bekerja sebagai pegawai swasta, dan ibu mertua yang tinggal serumah dengan subjek ikut berperan dalam hal pengasuhan anak khususnya saat subjek kembali bekerja.

Faktor internal yang mendorong dalam pemberian asi eksklusif

\section{Pengetahuan}

Pengetahuan merupakan salah satu faktor prediposisi yang menentukan perilaku kesehatan seseorang. Pengetahuan tersebut dapat diperoleh melalui pendidikan formal, penyuluhan dan informasi dari media masa. Selain itu pengetahuan juga diperolah berdasarkan pengalaman tertentu yang pernah dialami (Notoatmodjo, 2005)

Menurut Suradi (1989) yang mempengaruhi keberhasilan ASI salah satunya adalah pengetahuan ibu mengenai laktasi. Seseorang yang mempunyai pengetahui tentang ASI akan mempengaruhi yang dinyatakan dengan pola menyusui yang baik.

"Kalau ASI ya air susu ibu mba yang saya tau, kalau ASI eksklusif ya itu selama 6 bulan yang tanpa tambahan nutrisi lain"'(responden 4)

"Iya untuk kecerdasan bayi, untuk kesehatan, kalau pakai sufor jadi gampang sakit, kalau ASI kan lebih kuat dia. Jadi itu sih kegunaan ASI menurut saya" (responden1)

"buat bayi itu, untuk menambah daya tahan tubuhnya, karena dalam ASI itu saya bacabaca di internet katannya mengandung antibody buat bayi, supaya dia ngak cepet sakit, untuk mendekatkan bayi sama ibu, kayak hubungan batin gitu' (responden 10)

"Ya manfaatnya untuk kekebalan tubuh, untuk daya imun. Sama kan ya kekebalan tubuh sama daya imun",'Tau sih mba kayak semacam cairan yang pertama kali keluar itu kan mba yang warnanya kekuningan"(responden 3 )

"oh itu seperti skin to skin itu, saya ngak tau apa namanya, soalnya itu di lakukan pada saat sehabis melahirkan

"saya rasa itu berpengaruh, karena bayinya jadi tau dia mengenal puting untuk pertama kali, jadi dia ngak kenal dot susu dulu, kenal puting saya dulu, jadi terbiasa sampai sekarang" (responden 10)

"dari membaca buku dan dari orang orang yang bercerita"(responden 12)

"Sebelum saya berangkat biasanya pagi2 saya pompa dulu ASInya terus saya taruh di botol kaca ditutup rapat ditaruh di freezer"(responden 6)

"iya kalo menurut saya se, ibu-ibu itu harus bisa memberikan ASI walaupun bekerja. Mungkin ibunya males atau gimana maunya yang instan biar lebih cepat jadinya ngasih susu formula .Sebenernya itu biarpun bekerja bisa memberikan ASI eksklusif, dan sebenernya harus punya niat juga dalam memberikan asi eksklusif"'(responden 11)

Dari hasil penelitian tarhadap 12 responden yang lulus memberikan ASI eksklusif, ternyata pengetahuan tentang ASI eksklusif mencakup pengertian dan manfaat sangat baik dimana semua responden dapat menjelaskan secara luas dan mendetail. Salah satu renponden menjelaskan ASI eksklusif dan manfaatnya. ASI eksklusif pemberian ASI tanpa diberikan tambahan apapun sampai bayi berumur 6 bulan. Sedangkah manfaat pemberian ASI eksklusif adalah agar bayi sehat karena ASI banyak mengandung vitamin dan mineral sehingga bayi tidak terserang penyakit. Pengetahuan tentang kolostrum. Kolostrum adalah air susu pertama yang keluar yang berwarna kekuning-kuningan lebih kental dari ASI matang (mature). Seluruh responden mengerti tentang kolostrum dan hanya beberapa responden yang tidak mengetahui manfaat kolostrum.

Hasil penelitian ini sejalan dengan penelitian yang dilakukan oleh Ibrahim (2002), menyebutkan bahwa ibu yang berpengetahuan baik 1,9 kali berpeluang untuk memberikan ASI eksklusif 
dibandingkn dengan ibu yang berpengetahuan kurang. Begitu juga dengan penelitian Hartuti (2006) menyebutkan proporsi ibu yang memberikan ASI eksklusif dengan pengetahuan baik lebih besar 27,3\% disbanding dengan proporsi ibu yang memberikan ASI eksklusif dengan pengetahuan kurang hanya $3,8 \%$. Semakin tinggi tingkat pengetahuan, semakin tinggi ibu memberikan ASI eksklusif.

Pada penelitian Sari dan Evaputriningrum dalam Novitasari (2016) menunjukan bahwa, tingkat pengetahuan Ibu tentang gizi sangat penting dalam meningkatkan status gizi keluarga terutama balitanya. Hasil penelitian menunjukan bahwa sebagian besar ibu nifas memiliki pengetahuan baik mengenai nutrisi yang dapat meningkatkan produksi ASI, semakin banyak produksi ASI akan meningkat pemberian ASI eksklusif pada bayi.

Selain pengetahuan tentang gizi, ibu hamil perlu mendapat pengetahuan tentang Inisiasi Menyusu Dini ( IMD ), karena IMD merupakan salah satu cara untuk keberhasilan ibu dalam pemberian ASI eksklusif agar bayi tidak bingung puting. Dalam penelitian ini pengetahuan responden tentang IMD cukup baik, yang ditindaklanjuti dengan sikap dan perilaku pemberian ASI eksklusif. Hasil penelitian menunjukan bahwa dari 12 renponden yang lulus memberikan ASI eksklusif, sebanyak 9 responden melakukan Inisiasi Menyusu Dini ( IMD )

\section{Motivasi}

Motivasi adalah dorongan yang timbul dari dalam diri seseorang secara sadar atau tidak sadar sehingga membuat orang berperilaku mencapai tujuan yang sesuai dengan kebutuhannya. Persiapan psikologi selama kehamilan akan menunjang keberhasilan menyususi. Seorang ibu yang menyusui harus menjaga ketenangan pikiran, menghidari kelelahan, membuang rasa khawatir yang berlebihan dan percaya diri bahwa ASI nya mencukupi kebutuhan bayi. Ibu-ibu harus dibangkitkan kemauan dan kesediaannya untuk menyusui bayinya terutama sebelum melahirkan.

"Ohh saya ingin yang terbaik, soalnya sufor cuma gede di badan tidak semuanya bisa bagus untuk anaknya, biasanya kan anak asi sama anak sufor kan keliatan, dia emang besar kalau anak sufor, kalau anak ASI emang lebih kecil tapi lebih kuat, jadi itu dorongan saya kasih ASI" (responden 1)

Hasil wawancara dengan responden semua responden menyatakan sumber motivasi untuk memberikan ASI ekslusif dari diri sendiri. Berikut pernyataan dari responden.

"ya, dari sendiri aja sih mba" (responden 3).

Sebagian besar responden yang diwawancara menyatakan perasaan bahagia saat meyusui dan terjalin hubungan yang baik antara ibu dengan bayi. Adapun pernyataan dari responden sebagai berikut.

"Ya sangat bahagia ya mba bisa nyusuin anak apalagi bisa deket sama anak ada terjalin hubungan sama anak"(responden 4) "selain seneng ya, ngerasain bangga juga oo saya lo bisa saya ngasi asi yang benerbener eksklusif yang bener-bener dari niat saya, dan bayi emang jarang sakit, pokoknya bahagia ngak bisa di bilang pake kata kata" (responden 10)

Hampir semua ibu hamil memotivasi dirinya untuk dapat memberikan ASI eksklusif pada bayinya sejak masa kehamilan, termasuk ibu yang bekerja di luar rumah. (Fikawati, S. 2009). Hasil penelitian menunjukan bahwa sebagian besar yang memotivasi responden untuk memberikan ASI eksklusif pada bayinya adalah dari sendiri. Semua responden mempunyai keingian yang kuat untuk memberikan yang terbaik pada bayinya agar sehat, tumbuh dengan baik, tidak gampang sakit dan ada ikatan batin antara ibu dan bayi. Perkembangan anak melalui kontak fisik (kontak kulit), psikis (kontak mata), suara dan penciuman dilakukan melalui inisiasi dini atau pengenalan puting susu segera setelah bayi lahir. Interaksi ini meningkatkan hubungan batin ibu dan anak, menimbulkan rasa aman pada bayi, yang kelak akan meningkatkan rasa percaya diri pada anak.

\section{Ibu bekerja}

Beberapa wanita karier mempunyai kecemasan bahwa memberikan ASI eksklusif akan mempengaruhi kegagalan profesi dan organisasi kemasyarakatan mereka dan kemungkinan akan merusak prospek peningkatan karier. Anggapan ini telah berkembang dan merupakan masalah dalam keberhasilan pemberian ASI 
eksklusif, hal ini nyata dihadapi oleh banyak wanita karier (Sylvia,1997 dalam Almira 2011).

Hasil penelitian bagi ibu yang bekerja sebagian besar menyatakan asi dipompa dan disimpan di freezer. Adapun hasil pernyataan responden sebagai berikut.

"dulu saya sebelum melahirkan saya banyak baca baca dari internet juga, trus pas mau mendekati lahiran saya bertanya juga, saya di tuntun dan di bantu sama bidan bidannya"

"iya saya bekerja dek"

awal-awalnya saya se ngak masalah karena saya dapet cuti beberapa bulan. Tapi saya juga belajar dari pengalaman sodara yang sudah pernah melahirkan, jadi saya sudah menyiapkan saya pompa asi saya, kemudian asi saya simpen di dalam freezer, jadi saya sudah persiapkan semuanya. Jadi saya memompa setelah saya habis menyusui, jadi kan asinya masih banyak, jadi tidak perlu rangsangan, jadi walupun bayi saya tinggal bayi saya tetap mendapatkan ASI saya"'(responden 10)

Hasil penelitian menyatakan sebagian besar ibu tidak lulus ASI ekslusif karena bekerja. Berikut pernyataan dari responden tersebut.

"Itu sih sebenernya apa ya ee itu niat dari diri sendiri kan mba ya, sebenernya kan kasihan juga kan kalau anaknya ngga dikasi asi. Itu dari ibunya sendiri sih niat apa ngga kasih asi sama anaknya"'(responden 6)

Hasil penelitian ini menunjukan bahwa 12 responden yang memberikan ASI eksklusif, sebanyak 8 orang $(75 \%)$ adalah ibu yang bekerja formal sebagai wanita karier. Hasil wawancara mendalam bahwa seluruh responden dapat mempersiapkan ASI perah dengan baik pada saat bayi di tinggal kerja, sehingga mereka berhasil lulus memberikan ASI eksklusif pada bayinya. Pendapat responden bahwa bekerja dapat menghambat pemberian ASI eksklusif menurut mereka adalah tidak benar. Mereka mengatakan kalau ada niat dan motivasi yang tinggi pasti bisa, yang penting ada usaha dan pengorbanan untuk kepentingan kesehatan bayi.

Hal ini sesuai dengan informasi yang mereka terima baik dari tenaga kesehatan maupun media cetak dan elektronik, bahwa ibu bekerja dapat memberikan ASI perah pada bayinya saat di tinggal kekantor. ASI perah dapat dilakukan pada saat ibu di tempat kerja setiap 3 sampai 4 jam sekali, lalu disimpan di lemari es. Kegiatan menyususi dapat dilanjutkan pada malam hari, pagi hari sebelum berangkat kerja dan waktu luang ibu. Hal ini akan membantu produksi ASI tetap tinggi Almira 2011).

Walaupun ada sebagaian ibu bekerja yang dapat memberikan ASI eksklusif, tetapi penelitian yang dilakukan di Kecamatan Landono Kabupaten Konawe Selatan, Sulawesi Tenggara tidak sejalan dengan penelitian ini. Hasil penelitian menunjukan bahwa para ibu yang bekerja maupun kegiatan lainnya diluar rumah, pemberian ASI tidak dapat diberikan secara maksimal dan biasanya diberikan susu formula ( $\mathrm{La}$ Ode, AS. 2011).

Telaah literatur menurut Novayelinda, $R$. (2012) tetang pemberian ASI dan ibu bekerja menghasilkan bahwa pada prakteknya wanita bekerja lebih banyak memerah ASI untuk mempertahankan produksi ASI, disarankan pada wanita bekerja unruk memerah ASI setiap 3 sampai 4 jam sekali selam jam kerja. Oleh karena itu dibutuhkan fasilitas untuk memerah dan menyimpan ASI di tempat kerja. Waktu kerja yang fleksibel merupakan salah satu jalan keluar dari masalah stress dalam menyeimbangkan antara pekerjaan dan pemberian ASI. Hasil telaah literatur ini menyimpulkan bahwa wanita bekerja membutuhkan dukungan tertentu seperti istirahat untuk menyusui atau memerah ASI, ruangan khusus untuk menyusui dan informasi tentang manajemen laktasi. Wanita bekerja membutuhkan strategi khusus untuk mempertahankan produksi ASI. Hal ini bisa dilakukan dengan dukungan dari personal wanita bekerja yang berhasil memberikan ASI untuk meningkatkan motivasi dalam pemberian ASI.

\section{Sikap terhadap susu formula}

Sikap dan keyakinan menunjukan potensi seseorang atau dikenal dengan istilah determinasi diri. Individu yang tangguh, mampu bereaksi otentik dan murni, serta mempunyai kebenaran tentang kemantapan dan kekuatan dalam dirinya. Dengan modal ini ia mampu membuat keputusan atau menentukan sikap berdasarkan hak otonomi. Orang yang mantap dan kuat dalam bersikap, sadar akan keterbatasan dan kelemahan dirinya, tetapi tetap mengandalkan keputusasaan yang jujur dan murni. Ibu menghadapi tantangan menyususi dengan persiapan mental. Dalam pikiran ibu 
perlu pengorbanan untuk mendapatkan apa yang dipilihnya, mau berkorban untuk anak yang dilahirkan menunjukan ungkapan hati nurani yang mendalam

Responden menyatakan bahwa akibat dari adanya susu formula menyebabkan ibu malas menyusui tetapi ada pula yang menyatakan susu formula sangat mendukung bagi ibu yang tidak keluar air susu. Berikut pernyataannya.

"saya mendukung se ngak, ngak mendukung juga ngak, kan masih banyak juga ibu ibu yang air susunya tidak keluar, jadi harus memberikan sufor kepada bayinya"'(responden 7)

Hasil penelitian menunjukan bahwa seluruh responden berusaha agar dapat memberikan ASI pada bayinya sampai berumur 2 tahun. Keinginan ini muncul karena seluruh responden merasa bangga karena lulus memberikan ASI eksklusif. Menurut mereka belum tentu seluruh ibu dapat lulus memberikan ASI eksklusif karena berbagai faktor, seperti ASI yang tidak mencukupi, kesehatan ibu dan lain sebagainya.

Salah satu godaan pada ibu menyususi adalah mengganti ASI dengan susu formula. Ibu yang berhasil menyususi tidak tergoda karena ia sadar bahwa menggati ASI adalah salah. Hasil penelitian tentang sikap responden terhadap susu formula, mereka ada yang setuju dan ada yang menolak. Responden beranggapan bahwa dengan banyaknya beredar susu formula dengan berbagai jenis, akan menyebabkan ibu malas menyusui. Tetapi ada responden yang mendukung dengan adanya susu formula di pasaran, karena masih ada ibu yang tidak dapat memberikan ASI pada bayinya.

Menyusui adalah proses yang tidak datang dengan sendirinya, suka dan duka menyertai proses menyusui. Stres fisik karena nyeri luka jalan lahir dan puting sering terjadi. Stres psikis juga terjadi karena kenyamanan ibu terganggu. Ibu mengantisipasi hal ini sehingga dapat mengatasi stress yaitu dengan sikap, keyakinan serta pikiran yang positif, kepentingan pribadi dikesampingkan agar langkah menuju tujuan tercapai.

\section{KESIMPULAN DAN SARAN \\ Kesimpulan}

Pengetahuan yang baik tentang ASI sangat mendukung keberhasilan pemberian ASI eksklusif. Motivasi diri sendiri dan dukungan keluarga responden dapat mendorong keberhasilan pemberian ASI eksklusif. Perilaku IMD pada ibu dapat mendukung keberhasilan pemberian ASI eksklusif. Sebagian besar responden yang bekerja berhasil memberikan ASI eksklusif pada bayinya

\section{Saran}

Promosi ASI eksklusif perlu ditingkatkan untuk meningkatkan cakupan ASI eksklusif. Puskesmas, rumah sakit dan praktek bidan mandiri agar melakukan IMD pada pasiennya

\section{DAFTAR PUSTAKA}

Afifah, D. N. (2007). Faktor Yang Berperan Dalam Kegagalan Praktik Asi Eksklusif Studi Kualitatif di Kecamatan Tembalang Kota Semarang Tahun. Universitas Diponegoro Semarang.

Fikawati. S. Syafig A. (2009). Penyebab Keberhasilan dan Kegagalan Praktik Pemberian ASI Ekslusif. Kesehatan Masyarakat. Jurnal Kesehatan Masyarakat Nasional.

Haryani. (2014). Alasan Tidak di Berikan ASI Eksklusif Oleh Ibu Bekerja di Kota Mataram Nusa Tenggara Barat. Universitas Udayana Denpasar.

Kementerian Kesehatan RI. (2014). Sekertariat Jenderal Profil Kesehatan Indonesia. Jakarta : Kementerian Kesehatan RI. 2015 (online)

http://depkes.go.id/folder/view/01/stru cture-publikasi-pusdatin-profilkesehatan.html (diaskses pada tanggal (2 desember 2015)

La Ode, A.S. (2011). Faktor-faktor yang Menghambat Praktik Asi Eksklusif pada Bayi Usia 0-6 Bulan Desa Tridana Mulya, Kecamatan Landono Kabupaten Konowe Selatan Sulawesi Tenggara. Universitas Diponegoro Semarang.

Novitasari, L dan Ningrum, E. P. (2016). Tingkat Pengetahuan Ibu Nifas tentang Nutrisi yang dapat Meningkatkan Produksi ASI di BPS. Edi Suryaningrum. Godean Sleman Yogyakarta. Media Ilmu Kesehatan. $5(2)$

Mariastuti, N. M. D. (2010). Faktor - faktor yang Mempengaruhi Ibu dalam Pemberian Makanan Pendamping ASI 
Martini, N.K., Astuti N.P.W / Kesehatan Terpadu 1 (1) (2017)

( MP- ASI ) Pada Bayi umur 3-6 Bulan di Wilayah UPT Puskesmas Abiansemal I Kecamatan Abiansemal Kabupaten Badung. Universitas Udayana Denpasar.
Novayelinda, R. (2012). Pemberian ASI pada Wanita Bekerja. Jurnal Ners Indonesia.2(2).

Natia, R. W. (2013). ASI dan Pedoman Menyusui Yogyakarta : Nuha Medika 